\title{
Expected Skills of newly hired business education
}

\section{Graduates}

\author{
Ma. Germina Esquivel - Santos
}

Doctor of Philosophy -major in Educational Management, College of Management and Business Technology, Nueva Ecija University of Science and Technology, Cabanatuan City, Nueva Ecija, Philippines

\begin{abstract}
This study determined the expected skills of newly hired Business Education Graduates. The study is Descriptive in nature. Survey questionnaire and Convenience sampling were utilized in data gathering. For the Data treatment and analysis, frequency count, percentages and weighted mean were utilized. The results of the study revealed that Business Representatives expected the newly hired Business Education Graduates as possessing holistic skills such as Academic skills, Technical skills, and Personal and social skills.
\end{abstract}

Keywords-Expectation; Business Education; Academic skills, Technical skills, personal and social skills.

\section{INTRODUCTION}

Unemployment and underemployment have increased significantly within recent years. The annual unemployment rate in 2017 was estimated $5.7 \%$, and annual underemployment rate was $16.1 \%$ as reported by the Philippine Statistics Authority Office. Based on recent studies, there are numerous causes of unemployment and underemployment and one of which is lack of adequate training and education. As stated also in the report, based on educational attainment, $16.5 \%$ of the unemployed were college graduates, $14.6 \%$ were college undergraduates and $31.1 \%$ were high school graduates As can be seen from the report, the lack of competency among those individuals makes them less favored for they are seem raw since high school graduates having the highest percentage in the unemployment rate, need more to be honed and be developed holistically. This made them seem not ready for employment.

Most people believe and perceive that teaching and learning processes are derived from studies in academic classrooms only. But when students analyze everyday cognition, they will discover that school-based learning and learning in practical setting have significant discontinuities. They cannot assume that what they learn in school is enough theory for human learning. Nor can they make significant development toward improving school effectiveness without a better grasp of what makes school a special place for education with its particular strengths and problems. For these reasons, students need to enlarge their understanding of what out-of-school teaching and learning actually entail and how its characteristics compare with school-based learning activities. (Schibner and Sachs, 2003).

Universities and Colleges have only just begun to understand that knowledge, aside from what are found in books and lectures or on the internet is actually constructed in collaborations among learners, interaction with practitioners, and being in the field itself.

The research aimed to gather expected skills from newly hired Business Education Graduates as viewed by selected Business Representatives. This Research will serve as reflective evaluation. The information will be of guide to better provide the needed attributes and skills for Business Education Graduates.

\section{OBJECTIVES OF THE STUDY}

1. To describe the Expected Skills of Newly hired Business Education Graduates in terms of:

1.1 academic skills;

1.2 technical skills; and

1.3 personal and social skills.

2. To identify the type of skill most expected by employers.

3. To propose support activities for skills enhancement.

\section{METHODOLOGY}

The study is Descriptive in nature since its focus was determining the Expected Skills of Newly hired Business Education Graduates. The instruments utilized were questionnaire and convenience sampling. Available Business Representatives became the respondents of the study. A total 
of 24 Business Representatives were the respondents. For the Data treatment and analysis, frequency count, percentages and weighted mean were utilized.

\section{CONCEPTUAL FRAMEWORK}

The basis of the study is from the The RAND Research Institute and Graduate School of America (2003) as cited by Santos, (2005), as stated, knowledge has two dimensions, the explicit and the tacit. The explicit dimension deals with concepts, and the know whats, whereas the tacit dimensions deals with knowhow.

Know how is best manifested in work practices and skills. Since the tacit lives in action, it comes alive in and through doing things and in participation with each other and the world.

Universities and Colleges have only just begun to understand that knowledge rather than being found in books and lectures or on the internet is actually constructed in collaborations among learners. People learn most powerfully when they come together and explore the intensive aesthetic of practitioner communities.

\section{RESULTS AND DISCUSSION}

1. Expected Skills of Newly hired Business Education Graduates

1.1 Academic Skills

Table.1: As to Academic Skills

\begin{tabular}{|l|c|c|}
\hline \multicolumn{1}{|c|}{ ITEM } & WM & VI \\
\hline 1.1 know the basics in office work. & 3.96 & Expected \\
\hline 1.2 know all phases of his/her work and related matters. & 3.79 & Expected \\
\hline 1.3 do task and instructions correctly. & 4.33 & Most Expected \\
\hline $\begin{array}{l}1.4 \text { plan and organize work so as to make effective use of time, } \\
\text { materials and equipment. }\end{array}$ & 4.33 & Most Expected \\
\hline 1.5 organize and develop ideas to get things started. & 4.08 & Expected \\
\hline 1.6 simplify work or workload. field of & 4.42 & Most Expected \\
\hline $\begin{array}{l}1.7 \text { update knowledge about new development in the } \\
\text { specialization. }\end{array}$ & 3.92 & Expected \\
\hline 1.8 integrate other field of knowledge to enrich effective working. & 3.75 & Expected \\
\hline 1.9 detect errors and correct them. & 4.29 & Most Expected \\
\hline 1.10 accomplish work on time. & 3.92 & Expected \\
\hline 1.11 grasp situations and draw correct conclusion. & 4.07 & Expected \\
\hline General Weighted Mean & & \\
\hline
\end{tabular}

Table 1 shows the responses of the respondents regarding their expectations on the academic skills of newly hired Business Education Graduates, "simplify work or workload" got the highest weighted mean of 4.42 with a verbal interpretation of "Most Expected" and "detect errors and correct them." got the lowest weighted mean of 3.75 with a verbal interpretation of "Expected".
This means that, employers most expect their newly hired Business Education Graduates to have the competence of making their work easier for accomplishment. Work smart through finding means to accomplished task and save time. For primarily employees are hired for works to be done. As supported by Schwartz (2014) "Work simplification resulting to job accomplishment is valuing the company's time".

\subsection{Technical Skills}


Table.2: As to Technical Skills

\begin{tabular}{|c|c|c|}
\hline \multicolumn{3}{|l|}{ II. Technical skills } \\
\hline & WM & VI \\
\hline 2.1 develop techniques in the completion of work on time. & 3.96 & Expected \\
\hline 2.2 apply theories and experiences. & 4.00 & Expected \\
\hline 2.3 perform actual business duties and responsibilities. & 4.33 & Most Expected \\
\hline $\begin{array}{l}2.4 \text { apply ability in clerical work, typing, encoding, programming, } \\
\text { inventory work, check important documents, etc. }\end{array}$ & 4.42 & Most Expected \\
\hline 2.5 apply ability to operate/use office facilities/equipment. & 4.25 & Most Expected \\
\hline 2.6 perform work appropriately according to standards. & 4.25 & Most Expected \\
\hline 2.7 practice orderliness and accuracy of performance. & 4.21 & Most Expected \\
\hline 2.8 evaluate objectively and accurately his/her performance and output. & 4.21 & Most Expected \\
\hline 2.9 contribute in the attainment of the company's objective. & 4.21 & Most Expected \\
\hline General Weighted Mean & 4.20 & Most Expected \\
\hline
\end{tabular}

For the Technical Skills as Expectation of Employers from Newly hired Business Education Graduates, "apply ability in clerical work, typing, encoding, programming, inventory work, check important documents, etc." got the highest weighted mean of 4.42 with a verbal interpretation of "Most Expected" and "develop techniques in the completion of work on time." got the lowest weighted mean of 3.96 verbally interpreted also as "Expected".
The findings show that, employers most expect their employees to have the ability to apply theories learned to actual business operations. Simply because it is the basic.

As Loretto (2017) stated "Employers look for employees who require little supervision and direction to get work done in timely and professional manner".

\subsection{Personal and Social Skills}

Table.3: As to Personal and Social Skills

\begin{tabular}{|l|r|r|}
\hline \multicolumn{2}{|c|}{ III. Personal and social skills } \\
\hline & WM & VI \\
\hline 3.1 show concern for company facilities. & 4.38 & Most expected \\
\hline 3.2 get along with superiors and subordinates. & 4.54 & Most expected \\
\hline 3.3 show courtesy and respect for authority. & 4.79 & Most expected \\
\hline 3.4 show courtesy and respect for co-workers. & 4.83 & Most expected \\
\hline 3.4 come to office regularly. & 4.46 & Most expected \\
\hline 3.5 lead and inspire others to achieve given objective. & 4.21 & Most expected \\
\hline 3.6 communicate effectively. & 4.25 & Most expected \\
\hline 3.7 accept accountability. & 4.33 & Most expected \\
\hline 3.8 self-reliant, resourceful and willing to accept responsibility. & 4.75 & Most expected \\
\hline 3.9 respond to changing requirement and condition. & 4.50 & Most expected \\
\hline 3.10 help others to improve and progress in his/her craft. & 4.33 & Most expected \\
\hline 3.11 shows enthusiasm and interest towards his/her work as well & 4.33 & Most expected \\
as the work of others. & & \\
\hline 3.12 manage his/her time, and those of others. & 4.38 & Most expected \\
\hline 3.13 accept workload. & 4.42 & Most expected \\
\hline 3.14 share his/her expertise. & 4.50 & Most expected \\
\hline 3.15 wear the prescribed uniform/office attire. & 4.67 & Most expected \\
\hline General Weighted Mean & 4.78 & Most Expected \\
\hline
\end{tabular}


For the Personal and Social Skills, "show courtesy and respect for co-workers." got the highest weighted mean of 4.83 with a verbal interpretation of "Most Expected" and "practice orderliness and accuracy of performance." got the lowest weighted mean of 4.21 verbally interpreted also as "Most Expected".

The findings show that, Employers expect newly hired Business Education Graduates to show good professional relationship with co-employees for every employee is part of a team, working as a team and not working in isolation as what Deming (2017) said "Human interaction in the workplace involves team production, with workers playing off of each other's strengths and adapting flexibility to changing circumstances".

\section{Skill most expected by employers}

Table.4: Summary Table of Skills Expected by employers

\begin{tabular}{|l|c|c|}
\hline \multicolumn{1}{|c|}{ SKILLS } & AWM & VI \\
\hline 1. Academic Skills & 4.07 & Expected \\
\hline II. Technical Skills & 4.20 & Most Expected \\
\hline III. Personal and Social Skills & 4.78 & Most Expected \\
\hline Overall Weighted Mean & 4.35 & Most Expected \\
\hline
\end{tabular}

As can be seen on the table above, Personal and social skills got the highest Average Weighted mean of 4.78 with a verbal interpretation of "Most Expected"

The result implies that employers most expect and prefer the newly hired employees to have the personal and social skills over academic skills and technical skills because currently in the Industry, consumers prefer more social interaction, attention and pampering. They view business people as problem solvers, who will make wonders for them. According to research conducted by the Carnegie Institute of Technology (2016) " $85 \%$ of Financial success is specifically related to emotional intelligence". As supported by Economy (2017) "Being able to understand another person's problems, as well as to convey that your understanding gives them a space of comfort, is a great skill to employ in the workplace".

\section{Proposed Support Activities for Skills Enhancement}

Based on the Results of the study the following Support Activities may be proposed

\section{a. Strengthening Industry/Professional Organization Networking}

Partnership with Professional Organizations will provide opportunities and avenue for students to attend and participate with the activities provided and sponsored by the said organizations. These will give them first hand experience of being in the actual scene. Currently companies are into:

1. Contests - wherein the students will be able to do jobs for them like product conception, advertising and promotion development and even selling.

2. Research - wherein the students will be sent on the field and will be interacting with the clients.

\section{b. Peer Mentoring}

Senior students may adopt students from lower year levels and mentor/assist them with their class activities and undertakings. Weekly consultations may be done in order to have regular communication, interaction, and collaboration about their experiences which will somehow help improve the communication skills and emotional stability.

\section{c. Cross-Departmental Training}

Interacting with students from different fields will help the business students widen their perspective and horizons. Widening one's perspective is a way of enriching one's ideas, creativities and emotional sensitivities and stabilities.

\section{CONCLUSION}

As viewed on the above mentioned results of the study, the following conclusions were drawn:

1. Respondents expect the newly hired Business Education Graduates to possess the Academic skills, Technical Skills and Personal and Social Skills.

2. The type of skill most expected by the respondents from the newly hired Business Education Graduates is Personal and social skills.

3. Support Activities for Skills Enhancement may be proposed such as Strengthening Industry/Professional Organization Networking, Peer mentoring, and CrossDepartmental Training.

\section{RECOMMENDATION}

1. Newly hired Business Education Graduates may also be respondents to the same or similar research study since they are the focus of the said study.

2. Benchmarking on other University Activities and Practices which centers on the focus of the study.

3. Regular assessment on the students' development focusing not only on Academic and technical skills but also on Personal and Social Skills may be conducted. 
4. Continuous conduction of Tracer Studies which will serve as feedback mechanism.

\section{ACKNOWLEDGMENT}

Sincerest gratitude of the researcher to God Almighty for all the opportunities and blessings and to the respondents of this research study for their cooperation and help.

\section{REFERENCES}

[1] Adams, Susan, 2014, The 10 skills Employers most Want in 2015 Graduates Downloaded January 5, 2018

[2] Loretto, Penny, 2017, Employee Values are a Good Indicator of Success Downloaded November 15, 2017

[3] Dunham, Meaghan, 2017 What Employer want Downloaded January 5, 2018

[4] Economy, Peter, 20175 Emotionally Intelligent Skills Every Employer is Looking For Downloaded January 9, 2018

[5] Skwartz, Jeff, 2004,The Overwhelmed employee: Simplify the Work Environment, Learning Books, English Downloaded November 15, 2017

[6] Santos, Ma. Germina E., (2005), Office Training Expectations of Trainees and Trainors: A Basis for an Enhanced Office Training Program, A Masteral Thesis, College of the Immaculate Conception, Cabanatuan City, Nueva Ecija, Phils.

[7] Vilailuk, Chanwong(2004), On the Job Training Performance of students of selected Rajabhat Institute, Thailand, A Masteral Thesis, Central Luzon State University, Munoz, Nueva Ecija, Phils.

[8] acad.dev@une.edu.au

[9] Encarta Dictionary, Microsoft Encarta 2007

[10] http://www.cpu.edu.ph/dep/commerce/copraticumprogram.ht $\mathrm{m}$

[11] http://www.psy.gla.ac.uk/ steve/qee/gradattr.html

[12] http://www.tdcj.state.tx.us/publications/newsletter/JanFeb200 0/ training-v7no1.htm

[13] lsn.curtin.edu.au/tlf/tlf/scoufis.html

[14] http://www.national statistics office.gov.ph 